\title{
ROLE OF SUNKIST PEELS EXTRACT AGAINST THE LEVEL OF ESTRADIOL AND MATURITY OF FOLLICLE IN THE FEMALE WISTAR RAT
}

\author{
MAYA SARI MUTIA ${ }^{1 *}$, SUHARTINA ${ }^{2}$ \\ ${ }^{1}$ Department of Histology, Faculty of Medicine, Universitas Prima Indonesia. ${ }^{2}$ Department of Public Health, Faculty of Medicine, \\ Universitas Prima Indonesia, North Sumatera, Indonesia. E-mail: mayasarimutia11@gmail.com
}

Received: 15 January 2021, Revised and Accepted: 26 February 2021

\section{ABSTRACT}

Objective: The purpose of this study is to investigate the effect of Sunkist peel extract against the estradiol level and ovarian follicle in the female Wistar rats.

Methods: This study was used 25 rats that were divided into five groups, namely, control (Na-CMC), standard (ethinylestradiol), and Sunkist peels extract-I, II, and III (300 mg/kg BW, $450 \mathrm{mg} / \mathrm{kg} \mathrm{BW}$, and $600 \mathrm{mg} / \mathrm{kg} \mathrm{BW}$ ). After 14 days, all rats were sacrificed by chloroform inhalation, and the ovarium was excised to histopathology preparation; meanwhile, the blood was collected for the serum. The histology and serum were determined the percentage of each type of follicle and the estradiol level, respectively.

Results: The result of this study showed that increasing of the extract significantly increased not the level of estradiol level $(p<0.05)$ but also the percentage of secondary and de Graaf follicle $(\mathrm{p}<0.05)$. Nevertheless, the percentage of primordial and primer follicle decreased, followed by increasing the extract dosage $(\mathrm{p}<0.05)$.

Conclusion: It can be concluded that the Sunkist peels Sunkist peel increase both the level of estradiol serum and maturity of the follicle that increases the opportunity of female rats to be fertilized.

Keywords: Sunkist peels, Ethinylestradiol, Estradiol, Follicle.

(c) 2021 The Authors. Published by Innovare Academic Sciences Pvt Ltd. This is an open access article under the CC BY license (http://creativecommons.org/ licenses/by/4.0/) DOI: http://dx.doi.org/10.22159/ajpcr.2021v14i4.40788. Journal homepage: https://innovareacademics.in/journals/index.php/ajpcr

\section{INTRODUCTION}

Infertility is a common case which can be found today. This can be seen from the latest data, which was reported whether the prevalence of infertility was 9 to $18 \%$ in the general population. In 2008, 61,430 neonates born from assisted reproductive technology [1].

About $15 \%$ of married couples suffered from infertility that was around 48.5 million couples over the world. Meanwhile, about $17 \%$ of the couple living in the industrialized countries reported that they required treatment related to infertility, which can be caused by ovulation failure, tubal damage or endometriosis, or a low sperm count. When puberty, primary oocytes in primary follicles in the ovary undergo meiosis to form polar bodies and an ovum that will be released for conception during ovulation. Typically, the ovarium content 300,000 reserve follicles. However, around 400 follicles become mature and can be ovulated; meanwhile, remain $99.7 \%$ will degrade [2]. Ovulation is affected by various hormones such as follicle-stimulating hormone (FSH), luteinizing hormone (LH), estrogen, and progesterone. Before ovulation, estrogen takes a dominant role, while after ovulation is the progesterone. Normally, estrogen level before menopause or premenopause is $30-400 \mathrm{pg} / \mathrm{ml}$ and reduces when postmenopausal age into $0-30 \mathrm{pg} / \mathrm{ml}[2,3]$.

In Indonesia, "Badan Pusat Statistik" reported that around 39.8 million women were in the childbearing age. However, $10-15 \%$ of them were infertile [4]. Various factors can cause infertility; however, more than $70 \%$ come from female problems. Infertility in female can be caused by ovarium, uterine tube, uterine, hypothalamic, hypophysis, or systemic disease. Around $27 \%$ of the cases come from ovarium cause due to ovulation failure, either congenital or imbalanced hormones [5-8]

Various herbs enrich Indonesia. Some herbs may content phytoestrogens. Phytoestrogen is a natural compound from herbs, which has a similar structure with 17- $\beta$-estradiol (E2). It was a common sexual hormone among the female. The phytoestrogens are commonly found as isoflavone, prenylflavonoid, coumestans, and ligans [8]. One of the natural products that have these compounds is Sunkist (Citrus sinensis L. Osbeck) peels. Sunkist ethanol extract contains various phytochemicals; one is a flavonoid that the derivate may act as the phytoestrogen. Phytoestrogen has a similar structure to the $17-\beta$-estradiol (E2). It affects the ovulation cycle. Due to these reasons, this study was aimed to investigate the effect of Sunkist peel extract against the estradiol level and ovarian follicle in the female Wistar rats as the animal trial $[9,10]$.

\section{METHODS}

This study was an experimental study with post-test only group control design in June 2020 at the Pharmacology Laboratory at the Faculty of Medicine, Universitas Prima Indonesia. Health Research Ethics Committee from Universitas Prima Indonesia has approved the protocol of this study with registration no. 012/KEPK/UNPRI/V/2020.

The materials used in this study were $96 \%$ ethanol, Sunkist peels, sodium carboxymethylcellulose (Na-CMC), ethinylestradiol (Lynoral ${ }^{\circledR}$ ), distilled water, standard rat pellets, chloroform, alcohol, formalin, xylol, paraffin, and hematoxylin-eosin (HE) staining powder.

The Sunkist was obtained from one of the traditional markets in Medan City, then it was identified at the Medanese Herbarium at FMIPA, University of North Sumatra. Amount of 500 grams Sunkist peel was dried by aerating for 7 days then pulverized to become simplicia powder. The simplicia powder was extracted by maceration method. First, simplicia powder was macerated by $70 \%$ ethanol as a solvent in a ratio of 1:10 for 3 days. The mixture was stirred regularly every day. After 3 days, it was filtered by filter paper, and then, the residue 
was re-macerated with $600 \mathrm{ml}$ of $70 \%$ ethanol for 3 days. The filtered maceration and maceration were evaporated by rotary evaporator at a temperature of $70^{\circ} \mathrm{C}$ and then followed by concentrated using the oven at $40^{\circ} \mathrm{C}$ until they become thick extracts $[11,12]$.

After that, the ethanol extract of Sunkist peels was suspended into the sodium carboxymethylcellulose to form an oral suspension. The oral suspension used $0.5 \%$ sodium carboxymethyl cellulose as vehiculum. It was made by mixing 0.5 grams sodium carboxymethyl cellulose powder into $30 \mathrm{ml}$ hot distilled water in the mortar for $15 \mathrm{~min}$ until it formed a clear phrase. Then, it was grounded until homogenous and dissolved in a volumetric flask by the remaining distilled water. Moreover, this suspension was used to vehiculum for extract and standard drugs. Amount of $600 \mathrm{mg}, 900 \mathrm{mg}$, and $1200 \mathrm{mg}$ ethanol extract of Sunkist peel was dissolved into $10 \mathrm{ml}$ [11].

The treatment was performed into 25 rats that were divided into five groups. The rats as the animal trial were a female rat, 150-200 g of body weight. Each group was received the following treatments [13].

a. Control: The rats received $1 \mathrm{ml}$ of $0.5 \%$ sodium carboxymethyl cellulose suspension

b. Standard (ethinylestradiol $50 \mu \mathrm{g} / \mathrm{kgBB}$ ): The rats received $1 \mathrm{ml}$ of ethinylestradiol $\left(\right.$ Lynoral $^{\circledR}$ ) oral suspension

c. Sunkist peels extract-I (300 mg/kg BW): The rats received $1 \mathrm{ml}$ of an oral suspension of Sunkist orange peel extract at a dose of $300 \mathrm{mg} / \mathrm{kg}$ BW

d. Sunkist Peels Extract-II (450 mg/kg BW): The rats received $1 \mathrm{ml}$ of an oral suspension of Sunkist orange peel extract at a dose of $600 \mathrm{mg} / \mathrm{kg} \mathrm{BW}$

e. Sunkist Peels Extract-III (600 mg/kg BW): The rats received $1 \mathrm{ml}$ of an oral suspension of Sunkist orange peel extract at a dose of $1200 \mathrm{mg} / \mathrm{kg} \mathrm{BW}$.

All rats in each group can access food and drink freely and received some treatments for 14 days. After that, all rats were sacrificed by inhalation of chloroform in the closed room. After the rat was anastized, the rat's abdominal and chest wall were incised vertically, and the blood was collected from the cardiac punctured by $5 \mathrm{ml}$ spuit and $25 \mathrm{G}$ needle, and then, it was saved in a red tube. Furthermore, both ovarian tissues were obtained and rinsed in normal saline. After that, the tissues were soaked in buffer neutral formalin $10 \%$ and were stained by HE staining.

The estradiol level was determined from obtained serum by ELISA methods and performed in the Regional Healthy Laboratory in Medan. Meanwhile, Ovarian tissues stained by HE stain and evaluated by a microscope at $\times 40, \times 100$, and $\times 400$ magnified. The evaluated parameter in the ovarian tissues was the number of primordial, primer, secondary, de Graaf, corpus luteum, and atresia follicle as the percentage.

All data in this study were analyzed based on the normality of data from the Shapiro-Wilk test. If the data were normal, it was analyzed by one-way ANOVA, instead of the Kruskal-Wallis test. Furthermore, the analysis was continued by a post-hoc test for one-way ANOVA or MannWhitney U-test for the Kruskal-Wallis test.

\section{RESULTS}

Determination and phytochemicals screening

Sunkist as the sample has been identified in the Medanese Herbarium, University of North Sumatera. The result of the identification showed as the following:

Kingdom: Plantae

Division: Spermatophyta

Class: Dicotyledoneae

Ordo: Rustales

Family: Rutaceae

Genus: Citrus

Species: Citrus sinensis L. Osbeck

Local Name: Sunkist orange (Jeruk Sunkist)
After the Sunkist has been extracted, the extract underwent phytochemical screening, and it contained some phytochemicals included tannin, saponin, flavonoid, triterpene, and steroid.

\section{Estimation of estradiol level}

The estradiol level was determined from the obtained serum of rats by ELISA Methods. After that, the estradiol level was analyzed by One Way ANOVA and followed by post-hoc Test Tukey HSD. Table 1 is shown the result of the analysis.

Based on Table 1 above, all intervention groups showed significant differences in estradiol level one another. It was shown by the p-value and superscript that was obtained by one-way ANOVA and post-hoc test Tukey HSD.

\section{Estimation of follicle development}

Other than the estradiol level, this study also investigated the number of follicles in rats' ovarian tissue. The number of follicles was expressed as the percentage and shown by the following Table 2 .

Based on Table 2 above, it can be seen that the number of primordial, primer, secondary, and de Graaf follicle was significant difference due to p-value lower than 0.05 . The further analysis showed that the increasing Sunkist peels extract dosage reduced percentage of primordial and primer follicle but increased percentage of secondary and de Graaf follicle. The remain follicle, namely, corpus luteum and atresia, was not shown a significant change in the percentage. It can be seen in p-value that higher than 0.05 . Fig. 1 is shown histology of the ovarian structure.

Based on the Fig. 1 above, ovarium was a structure that consists of cortex and medulla part and lined by germinal epithelium. All types of follicles can be found in the cortex of ovarium such as the primordial, primer, and atresia follicle shown by the figure above. Furthermore, the clear structure of each follicle can be seen in the following Fig. 2.

Based on the Fig. 2 above, it can be seen the structure of primordial, primer, and secondary follicle at $\times 400$ magnified. Primer follicle was characterized by an oocyte that was lined by a single layer of squamous follicular cells. The primordial follicle will develop into primer follicle. The single layer of follicular cells transformed into cuboid form and form primer follicle. Over time, the primer follicle develops into the secondary follicle. Follicular layer develops to form a more stratified structure known as granulosa zone, and the follicle also develops an antrum in a pole of the follicle. The antrum will become wider at the appropriate time, and the corona radiata and cumulus oophorus around the oocyte become more obvious. Hence, the secondary follicle develops into de Graaf follicle. Fig. 3 is shown the microscopic view of de Graaf follicle in the two different magnified.

Fig. 3 above is shown that the de Graaf follicle had wider antrum structure and obvious cumulus oophorus and corona radiata as de Graaf follicle's specific properties.

\section{DISCUSSION}

The result of this study clearly answered the purpose of this study to investigate the effect of Sunkist peel extract against the estradiol level and ovarian follicle. Ethanol extract of Sunkist obviously affects the estradiol

Table 1: Analysis of the estradiol serum level in all intervention groups

\begin{tabular}{lll}
\hline Groups & Level of estradiol $(\mathbf{p g} / \mathbf{m l})$ & p-value \\
\hline Control & $34.00 \pm 1.58^{\mathrm{a}}$ & $<0.05$ \\
Standard & $53.60 \pm 1.14^{\mathrm{b}}$ & \\
Sunkist peels extract-I & $43.80 \pm 1.30^{\mathrm{c}}$ & \\
Sunkist peels extract-II & $46.20 \pm 1.30^{\mathrm{c}}$ & \\
Sunkist peels extract-III & $49.00 \pm 1.58^{\mathrm{d}}$ & \\
\hline
\end{tabular}

Data were expressed as Mean \pm SD and $P$ value was obtained by one-way ANOVA.

Different superscript in the same column significantly differentiates according

to post-hoc test Tukey HSD 
Table 2: Analysis of the percentage of follicle in all intervention groups

\begin{tabular}{|c|c|c|c|c|c|c|}
\hline \multirow[t]{2}{*}{ Groups } & \multicolumn{6}{|c|}{ Percentage of follicle (\%) } \\
\hline & Primordial & Primer & Secondary & De Graaf & Corpus Luteum & Atresia \\
\hline Control & $65.98 \pm 0.55^{\mathrm{a}}$ & $27.82 \pm 1.19^{a}$ & $5.35 \pm 1.55^{\mathrm{a}}$ & $0.75(0.00-1.5)^{\mathrm{a}}$ & $0.00(0.00-0.50)$ & $0.00(0.00-0.00)$ \\
\hline Sunkist peels extract-I & $51.06 \pm 0.75^{c}$ & $37.75 \pm 1.09^{c}$ & $9.79 \pm 1.68^{c}$ & $1.00(0.00-1.50)^{\mathrm{a}}$ & $0.00(0.00-1.25)$ & $0.00(0.00-0.25)$ \\
\hline Sunkist peels extract-II & $43.95 \pm 1.11^{\mathrm{d}}$ & $34.39 \pm 0.95^{\mathrm{d}}$ & $14.83 \pm 2.70^{\mathrm{d}}$ & $3.50(2.50-4.00)^{\mathrm{c}}$ & $1.00(0.00-1.50)$ & $0.00(0.00-0.25)$ \\
\hline Sunkist peels extract-III & $45.34 \pm 0.79^{\mathrm{e}}$ & $34.18 \pm 1.80^{\mathrm{e}}$ & $17.55 \pm 1.03^{\text {bd }}$ & $4.50(3.40-5.00)^{\mathrm{d}}$ & $1.00(0.00-2.00)$ & $0.50(0.00-0.50)$ \\
\hline p-value & $<0.05^{*}$ & $<0.05^{*}$ & $<0.05^{*}$ & $<0.05^{* *}$ & $0.088^{* *}$ & $0.157^{* *}$ \\
\hline
\end{tabular}

*Data were expressed as mean \pm SD and P value was obtained from the one-way ANOVA and followed by post-hoc test Tukey HSD, **Data were expressed as

median (min-max) and P value was obtained from Kruskal-Wallis test and followed by Mann-Whitney U-test; Different superscript in the same column significantly differentiates according to either post-hoc test Tukey HSD or Mann-Whitney U-test

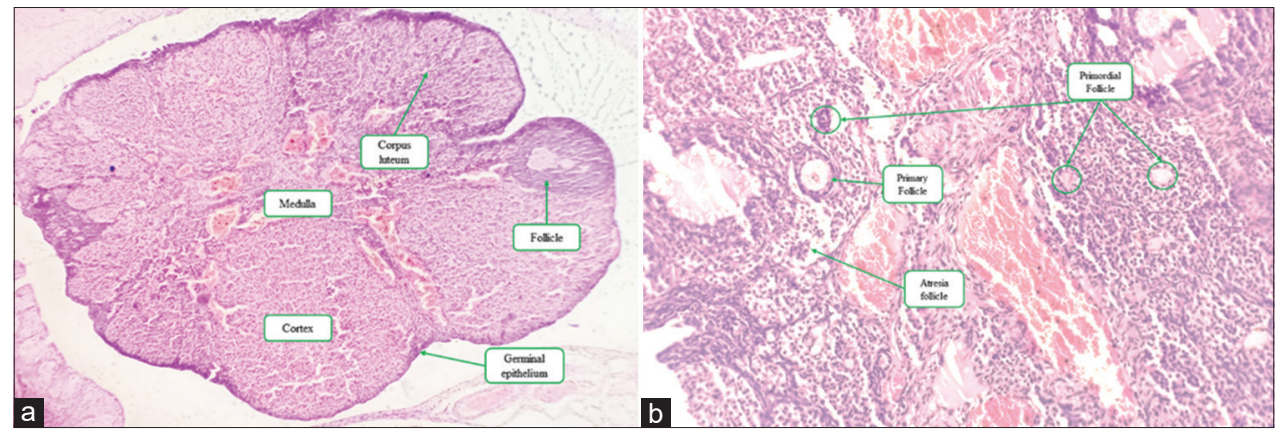

Fig. 1: Overview of rat ovarium: (a) Cortex and medulla of ovarium (Magnified: $\times 40)$ and (b) Cortex of ovarium (Magnified: ×100). Longitudinal section. Stain: HE Staining

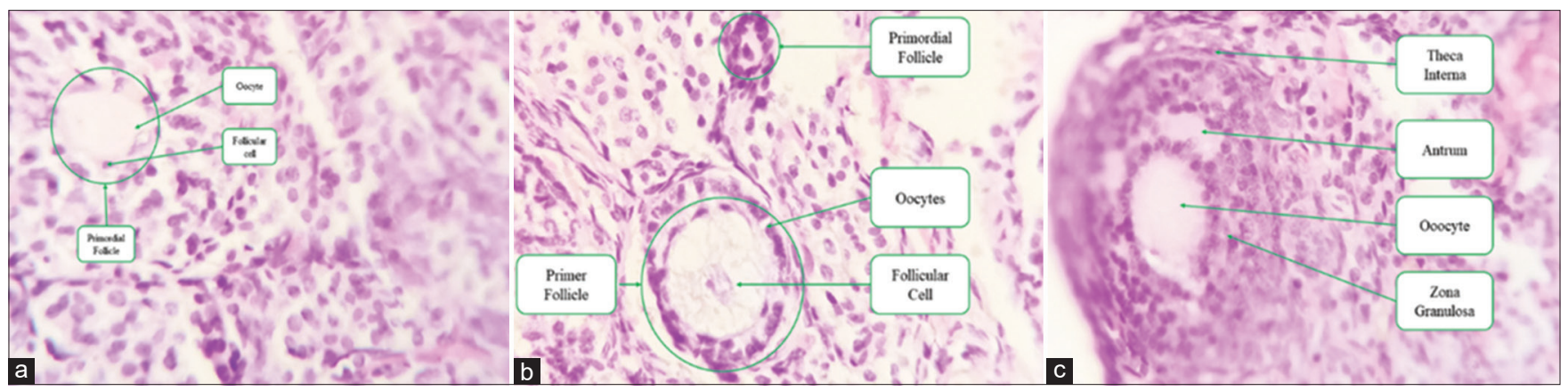

Fig. 2: (a) Primordial follicle, (b) Primer follicle, and (c) Secondary follicle in cortex of rat ovarium. $\times 400$ Magnified. Longitudinal section. Stain: HE Staining

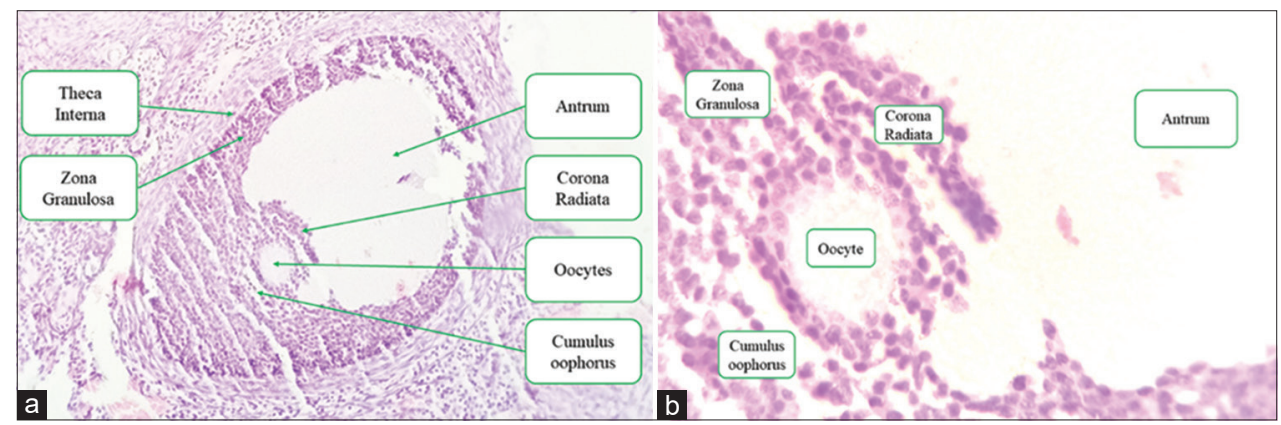

Fig. 3: de Graff Follicle: (a) 100 x magnified and (b) 400x Magnified. Longitudinal Section. Stain: HE Staining

level and significantly affects the follicle's percentage in the ovarium. The increasing of extract dosage increases estradiol serum level, but it was not as high as standard drugs. Moreover, this study was also shown that the increasing of extract dosage increased percentage of secondary and de Graaf follicle but reduced percentage of primordial and primer follicle.
The development of primordial follicle affects by the FSH. Moreover, this hormone will affect the primordial follicle's maturity into the primer and secondary hormone as long as the follicular layer was developed more stratified that will increase the level of estrogen hormone. It due to the secretion of hormone occurred in the follicular cell. The precursor 
of estrogen was formed in the theca cell; after that, it diffused into the follicular cell and converted into estradiol by $17 \beta$-HSD or estrone by aromatase. FSH regulated the expression of these enzymes $[2,14,15]$.

The increasing maturity of follicle affects the level of estrogen. The high level of estrogen has two main effects on the maturity of the follicle. First, it gives positive feedback against the hypothalamic-hypophysis to amplify the secretion of estrogen hormone while the granulosa cell is secreting inhibin to reduce the secretion of FSH. Another effect is the induction of ovulation; however, it also required the LH surge to induce the ovulation $[2,14,16]$.

These information support the result of this study. The increasing of estradiol level causes the increasing number of secondary and de Graaf follicle. However, the increasing estradiol level was not occupied by LH surge; hence, the ovulation did not occur. On the other hand, the percentage of primordial and primer follicle was reduced; it was caused by the increasing number of these follicles developed into the more mature follicle.

None of the studies investigates the effect of Sunkist peels against female fertility by in-vivo methods. Nevertheless, an in-vitro study has been performed to determine the phytoestrogen level of Sunkist peel. Phytoestrogen has a similar structure to endogen estradiol and binds with alpha and beta receptors of estrogen. Moreover, this complex will influence the gene expression of the cell. Kuhnle et al. reported that orange peels contented $36 \mu \mathrm{g} / 100 \mathrm{~g}$ wet weight of phytoestrogen based on the liquid chromatography-mass spectrometry and ${ }^{13} \mathrm{C}$-Labelled standard [17]. Another study performed by Shalaby and Shanab on the both $C$. sinensis leaf and Citrus aurantifolia peel reported that flavanones, flavones, and flavonols could act as powerful estrogen-like activity $[13,18,19]$.

Further study was required to investigate the role of other hormones such as FSH, LH, and progesterone simultaneously against the follicle development and it should be performed as a multidiscipline study to support the result of this study.

\section{CONCLUSION}

It can be concluded that the Sunkist peel can increase the level of estradiol serum and increase the develop of de Graaf follicle that can increase the opportunity of female rats to be fertilized.

\section{ACKNOWLEDGMENTS}

The author(s) disclosed receipts of the financial support for the research and/or publication of this article.

\section{AUTHORS' CONTRIBUTION}

Maya Sari Mutia - Writing manuscript, evaluation of microscopic view, concept and designing the study, and final approval. Suhartina - Data collection, data analysis, interpretation of data, and final approval.

\section{CONFLICT OF INTEREST}

The authors declare that there was no conflict of interest.

\section{AUTHORS FUNDING}

This study was fully funded by the Ministry of Research, Technology, and Higher Education by Funding Contact No. 282/LLI/PG/2020.

\section{REFERENCES}

1. Hanson B, Johnstone E, Dorais J, Silver B, Peterson CM, Hotaling J. Female infertility, infertility-associated diagnoses, and comorbidities: A review. J Assist Reprod Genet 2017;34:167-77.

2. Sherwood L. Fisiologi Manusia dari Sel ke Sistem. Jakarta: EGC; 2013. p. 811-70.

3. Simon A, Chang WY, DeCherney AH. Amenorrhea. In: DeCherney AH, Nathan L, Lauger N, Roman AS, editors. Current Diagnosis and Treatment Obstetrics and Gynecology. $11^{\text {th }}$ ed. New York: McGrawHill Medical; 2013. p. 1514-35.

4. Sharma S, Khinchi MP, Agrawal D, Sharma N, Gupta MK. Female infertility: An overview. Int J Pharm Sci Res 2011;2:1-12.

5. Hestiantoro A, Wiweko B, Pratama G, Yusuf D. Konsensus Penanganan Infertilitas. Jakarta: HIFERI, PERFITRI, IAUI, POGI; 2013. p. 1-81.

6. Agarwal A, Mulgund A, Hamada A, Chyatte MR. A unique view on male infertility around the globe. Reprod Biol Endocrinol 2015;13:37.

7. Hoffman BL, Schorge JO, Bradshaw KD, Halvorson LM, Schaffer JI, Corton MM. Williams Gynecology. $3^{\text {rd }}$ ed. New York: McGraw-Hill Education; 2016. p. 437-48.

8. Oikeh EI, Oriakhi K, Omoregie ES. Proximate analysis and phytochemical screening of citrus sinensis fruit wastes. Bioscientist 2013;1:164-70.

9. Rietjens IM, Louisse J, Beekmann K. The potential health effects of dietary phytoestrogens. Br J Pharmacol 2017;174:1263-80.

10. Sa'adah N, Purnomo W. Karakteristik dan Perilaku berisiko pasangan infertil di klinik fertilitas dan bayi tabung tiara cita rumah sakit putri Surabaya. J Biom Kependud 2016;5:61-9.

11. Mutia MS, Chiuman L. Hepatoprotective effect of Citrus sinensis (L.) osbeck ethanol extract in paracetamol-induced rats. Maj Kedokt Bandung 2019;51:189-93.

12. Kosasih E, Chiuman L, Lister INE, Fachrial E. Hepatoprotective effect of Citrus sinensis peel extract against isoniazid and rifampicin-induced liver injury in wistar rats. Maj Obat Tradis 2019;24:197-203.

13. Maheshwari H, Satyaningtijas AS, Harlina E, Ningsih UC, Effendi M, Mustofa MA, et al. The role of fennel infusion on estrous cycle and follicles development of white rats. J Ilmu Kefarmasian Indones 2016;14:19-25.

14. Hall JE. Guyton and Hall: Textbook of Medical Physiology. $13^{\text {th }}$ ed. London: Elsevier; 2017. p. 945-61.

15. Sharaibi OJ, Afolayan AJ. Biochemical and hormonal effects of Nymphaea lotus aqueous extract on hyperprolactinemic female wistar rats. Asian J Biochem 2017;12:91-8.

16. Ugwah-Oguejiofor CJ, Bello SO, Okolo RU, Etuk EU, Ugwah MO, Igbokwe VU, et al. Effect of aqueous extract of Ficus platyphylla on female wistar rats with estradiol valerate-induced polycystic ovarian syndrome. Int J Phytomed 2014;6:405-11.

17. Kuhnle GG, Dell'Aquila C, Aspinall SM, Runswick SA, Joosen AM, Mulligan AA, et al. Phytoestrogen content of fruits and vegetables commonly consumed in the UK based on LC-MS and 13C-labelled standards. Food Chem 2009;116:542-54.

18. Desmawati D, Sulastri D. Phytoestrogens and their health effect. Open Access Maced J Med Sci 2019;7:495-9.

19. Shalaby EA, Shanab SM. Antioxidant compounds, assays of determination and mode of action. Afr J Pharm Phamacol 2013;7:528-39. 